\title{
A surveillance of enteropathogens in piglets from birth to seven days of age in Brazil ${ }^{1}$
}

\author{
Eduardo C. Cruz Junior ${ }^{2}$, Felipe M. Salvarani ${ }^{2}$, Rodrigo O.S. Silva ${ }^{2}$, Marcos X. Silva $^{2}$, \\ Francisco C.F. Lobato ${ }^{2}$ and Roberto M.C. Guedes ${ }^{2 *}$
}

\begin{abstract}
Cruz Junior E.C., Salvarani F.M., Silva R.O.S., Silva M.X., Lobato F.C.F. \& Guedes R.M.C. 2013. A surveillance of enteropathogens in piglets from birth to seven days of age in Brazil. Pesquisa Veterinária Brasileira 33(8):963-969. Escola de Veterinária, Universidade Federal de Minas Gerais, Av. Antônio Carlos 6627, Cx. Postal 567, Belo Horizonte, MG 30123-970, Brazil. E-mail: guedesufmg@gmail.com

The purpose of the study was to evaluate the real importance of anaerobic enteropathogens and rotavirus in contrast to more common agents as cause of diarrhea in piglets within the first week of life. Sixty 1- to 7-day-old piglets, 30 diarrheic and 30 non-diarrheic (control), from 15 different herds were selected, euthanized and necropsied. Samples of the jejunum, ileum, colon, cecum and feces were collected from the piglets and analyzed to determine the presence of the following enteropathogens: enterotoxigenic Escherichia coli (ETEC), Clostridium perfringens types A and C, Clostridium difficile, rotavirus and Isospora suis. Among diarrheic piglets, $23.3 \%$ were positive for $C$. difficile, $70 \%$ for $C$. perfringens type A cpb2+, 14.3\% for rotavirus and 10\% for ETEC. Among non-diarrheic control piglets, $10 \%$ were positive for $C$. difficile, $76.7 \%$ for $C$. perfringens type A cpb2+, $0 \%$ for rotavirus, $3.3 \%$ for ETEC and 3.3\% for I. suis. C. perfringens type C was not detected in any of the animals. Histological lesions characteristic of $C$. difficile, $E$. coli and rotavirus were observed. However, no C. perfringens type A suggestive lesions were detected. There was a positive correlation between mesocolon edema and the presence of $C$. difficile toxins. Although $C$. perfringens type A cpb2+ was the most frequently detected enteropathogen, there was no association between its presence and diarrhea or macro or microscopic changes. C. difficile and Rotavirus were the most relevant pathogens involved with neonatal diarrhea in this study, and histopathology associated with microbiological test proved to be the key to reach a final diagnosis.
\end{abstract}

INDEX TERMS: Piglet, swine, Clostridium perfringens, Clostridium difficile, enterotoxigenic Escherichia coli, rotavirus.

RESUMO.- [Levantamento dos enteropatógenos de leitões do nascimento a sete dias de idade no Brasil.] 0 objetivo do presente estudo foi avaliar a real importância de enteropatógenos anaeróbios e rotavirus em comparação à outros agentes mais comuns como causa de diarreia em leitões até cinco dias de idade. Leitões com 0 a 7 dias de vida, 30 diarreicos e 30 não diarreicos (controles) de 15 granjas diferentes foram eutanasiados e necropsiados. Amostras de jejuno, íleo, colon e ceco foram coletadas e

\footnotetext{
${ }^{1}$ Received on February 5, 2013.

Accepted for publication on May 23, 2013.

${ }^{2}$ Escola de Veterinária, Universidade Federal de Minas Gerais (UFMG), Av. Antônio Carlos 6627, Cx. Postal 567, Belo Horizonte, MG 30123-970, Brazil. *Corresponding author: guedesufmg@gmail.com
}

submetidas à detecção dos seguintes enteropatógenos: Escherichia coli enterotoxigênica (ETEC), Clostridium perfringens, Clostridium difficile, rotavirus e Isospora suis. Entre os animais diarréicos, $23.3 \%$ foram positivos para $C$. difficile, $70 \%$ para C. perfringens tipo A cpb2+, $14.3 \%$ para rotavirus e $10 \%$ para ETEC. Entre os leitões não-diarréicos, $10 \%$ foram positivos para $C$. difficile, $76.7 \%$ para $C$. perfringens tipo A cpb2+, 3.3\% para ETEC e 3.3\% for I. suis. C. perfringens tipo $\mathrm{C}$ não foi detectado em nenhum animal. Lesões histológicas características de $C$. difficile, E. coli e rotavirus foram observadas. Por outro lado, nenhuma lesão sugestiva de $C$. perfringens foi detectada. Foi possível observar uma correlação positiva entre edema de mesocolon e presença das toxinas A/B. Apesar de C. perfringens tipo A cpb2+ ter sido o patógeno mais encontrado, nenhuma associação 
com lesões foi encontrada. C. difficile e Rotavirus foram os agentes mais relevantes associados à diarreia neonatal, e ficou demonstrada a relevância de associação de histopatologia com testes de detecção microbiológica para se firmar um diagnóstico.

TERMOS DE INDEXAÇÃO: Leitões, suínos, Clostridium perfringens, Clostridium difficile, Escherichia coli enterotoxigênica, rotavirus.

\section{INTRODUCTION}

Enteric disorders are the most common group of infectious diseases in piglets during the first week of life. They are responsible for significant economic losses, mainly due to reductions in weaning weight and increases in mortality rates and production costs. Thus, it is essential to obtain information concerning the actual relevance of each enteropathogen to allow specific preventive measures and more efficient control methods to be used.

The most important pathogens associated with diarrhea in piglets up to seven days of age are enterotoxigenic Escherichia coli (ETEC), Clostridium perfringens types A and C, Clostridium difficile, rotavirus and Isospora suis (Yaeger et al. 2002). However, some recent reports indicate that the frequency of these agents has been changing, with microorganisms such as $C$. difficile becoming more prevalent (Yaeger 2007).

Additionally, the real importance of $C$. perfringens type A as a primary agent of diarrhea in suckling piglets is not fully known. Information regarding the detection and prevalence of intestinal pathogens in piglets is scarce. The purpose of our study was to evaluate the real importance of anaerobic enteropathogens and rotavirus in contrast to more common agents as cause of diarrhea in piglets within the first week of life.

\section{MATERIALS AND METHODS}

\section{Farms and animals}

Stool samples were collected from 1- to 7-day-old piglets from 15 different farms with at least 500 sows in a three-site production system located in a densely swine-populated area of Minas Gerais, Brazil. On each farm, two diarrheic based on clinical signs and two apparently healthy piglets $(n=60)$ were sedated with xylazine (Virbac ${ }^{\circledR}$, Brazil; 0.3 to $5 \mathrm{mg} / \mathrm{kg}$ IM), euthanized by electrocution and exsanguinated. Each piglet was selected from a different litter. Parity of dam wasn't considered. Samples were collected for histology, bacteriology and molecular assays. Stool samples were collected directly from the rectum and stored at $4^{\circ} \mathrm{C}$ for up to 48 hours. Samples of the jejunum, ileum, cecum and colon were fixed in $10 \%$ buffered formalin. All procedures performed were approved by the Ethics Committee on Animal Experiments of the Universidade Federal de Minas Gerais (CETEA-UFMG, protocol no.30/09).

\section{Enterotoxigenic Escherichia coli}

Stool samples were plated on MacConkey agar (Biobrás ${ }^{\circledR}$, Prodimol Biotechnology) followed by incubation at $37^{\circ} \mathrm{C}$ for 24 hours. Each isolated colony was subjected to biochemical testing as previously described (Martins et al. 2000). All colonies identified as E. coli by biochemical assay were subjected to DNA extraction by the phenol-chloroform method (Sambrook et al. 1989). DNA concentrations were estimated in a spectrophotometer (Shimadzu ${ }^{\circledR}$, model UV160A). Samples were diluted to a final concentration of $10 \mathrm{ng} / \mu \mathrm{L}$ prior to performing multiplex PCR for E. coli pathogenicity factor genes (Macêdo et al. 2007). Four strains, kindly provided by the Veterinary Diagnostic Laboratory at the University of Minnesota, were used as positive controls for PCR: 2568 (STb, STaP, F18 and Stx2e), 2569 (STb, LT and K88), 2570 (987P and STaP) and 2571 (STaP, K99 and F41). Amplification products were visualized by electrophoresis in $6 \%$ polyacrylamide gels followed by silver staining (Macêdo et al. 2007).

\section{Clostridium perfringens}

For isolation of $C$. perfringens, 0.08 to $0.12 \mathrm{~g}$ of feces was serially diluted from 10-1 to 10-6. Aliquots of about 50 $\mu \mathrm{L}$ of each dilution were plated on sulfite polymyxin sulfadiazine agar (SPS, Difco Laboratories, Detroit, USA) and incubated anaerobically at $37^{\circ} \mathrm{C}$ for 24 hours. Following incubation, DNA was extracted from characteristic Clostridium sp. colonies (Baums et al. 2004) and used for PCR. Genes encoding beta-2 toxin (cpb2), enterotoxin (cpe) and the major C. perfringens toxins (alpha, beta, epsilon and iota) were detected using multiplex PCR (Vieira et al. 2008). The products were visualized under UV light in a $2 \%$ agarose gel stained with ethidium bromide (Sigma-Aldrich, Saint Louis, USA).

\section{Clostridium difficile}

C. difficile A/B toxins were detected using an ELISA kit (Ridascreen Clostridium difficile toxins A/B, R-Biopharm, Germany). All reactions were performed according to the manufacturer's instructions.

\section{Rotavirus}

Stool samples were diluted in Tris- $\mathrm{HCl} \mathrm{CaCl} 2$ buffer as previously described (Barbosa et al. 1998). RNA was extracted using the phenol-chloroform method (Theil et al., 1981; Sambrook et al., 1989). Each sample was then subjected to discontinuous polyacrylamide gel electrophoresis (PAGE; 7\% running gel, 3.45\% stacking gel; Sigma-Aldrich; according to Barbosa 1994) followed by silver staining (Herring et al. 1982).

\section{Isospora suis}

Coccidia oocysts (Eimeria spp. and I. suis) were detected using the flotation method with Sheather's sugar solution followed by light microscopy (Hoffmann 1987).

\section{Histopathology}

Formalin-fixed samples of the jejunum, ileum, cecum and colon were subjected to dehydration, diaphanisation and paraffin inclusion. Five-micron sections of each part of intestine were prepared and stained with hematoxylin and eosin (Luna 1968), and histological evaluation was performed using light microscopy.

\section{Statistical analysis}

Fisher's exact test (Data Analysis and Statistical Software Stata, Tulsa, Oklahoma, EUA) was used to analyze the results. P values of $<0.05$ were considered significant.

\section{RESULTS}

\section{Escherichia coli}

Of the 60 piglets sampled, pathogens were not detected in nine of them, three diarrheic and six controls. All samples from both groups showed lactose-positive colonies on MacConkey agar. After biochemical testing, 22 isolates from the diarrheic group and 24 isolates from the control group were classified as lactose-positive E. coli. 
Table 1. Frequency of enteric pathogens in piglets one to seven days old

\begin{tabular}{lccccc}
\hline $\begin{array}{l}\text { Enteropathogen } \\
\begin{array}{l}\text { (Detection } \\
\text { method) }\end{array}\end{array}$ & $\begin{array}{c}\text { Clostridium } \\
\text { difficile } \\
\text { (ELISA) }\end{array}$ & $\begin{array}{c}\text { Rotavirus* } \\
\text { (PAGE) }\end{array}$ & $\begin{array}{c}\text { Clostridium } \\
\text { perfringens } \\
\text { type A cpb2+ } \\
\text { (PCR) }\end{array}$ & $\begin{array}{c}\text { ETEC } \\
\text { (PCR) }\end{array}$ & $\begin{array}{c}\text { I. suis } \\
\text { (Fluctuation) }\end{array}$ \\
\hline $\begin{array}{l}\text { Diarrheic piglets } \\
\begin{array}{l}\text { Non-diarrheic } \\
\text { piglets (control) }\end{array}\end{array}$ & $10 \%(3 / 30)$ & $0 \%(0 / 30) B$ & $70 \%(21 / 30)$ & $10 \%(3 / 30)$ & $0 \%(0 / 30)$ \\
Herds & $40 \%(6 / 15)$ & $26.7 \%(4 / 15)$ & $100 \%(15 / 15)$ & $26.7 \%(4 / 15)$ & $6.7 \%(1 / 15)$
\end{tabular}

* Values followed by different letters in the same column differ significantly $(\mathrm{p}<0.05)$.

Only four of the piglets, each from a different farm, were positive by PCR for the presence of virulence factor genes (Table 1). Three belonged to the diarrheic group and had the following virulence types: F41, 987P and 987P-LT. The one remaining piglet from the control group was positive for the 987P-LT gene. However, only one diarrheic piglet (987P-LT) had a large number of coccobacilli adhered to the enterocyte surface (Fig.1), which is a characteristic histological finding of enterotoxigenic E. coli infection. No difference was observed between diarrheic and control groups regarding enterotoxigenic $E$. coli detection ( $\mathrm{p}=0.741)$.

\section{Clostridium perfringens}

Suggestive colonies of $C$. perfringens were recovered from 22 diarrheic piglets and 26 control piglets. C. perfringens type A was identified by PCR from all 15 farms investigated, demonstrating the high frequency of this agent, which is a normal part of the piglets' microbiota. C. perfringens

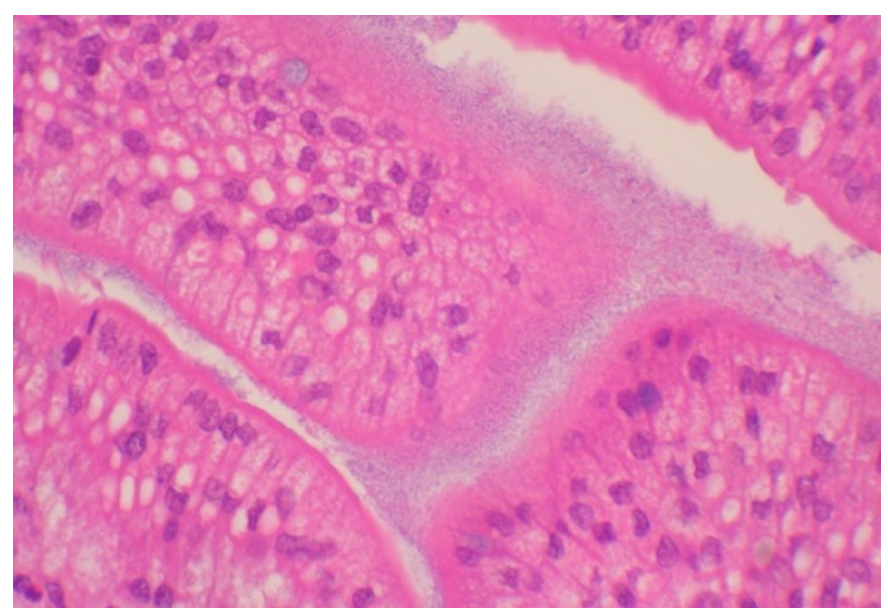

Fig.1. Piglet jejunum showing intense adhesion of coccobacilli in villus enterocytes (arrows) consistent with enterotoxigenic Escherichia coli infection. HE, 400x. type $\mathrm{C}$ was not found in any of the piglets. All farms had at least one piglet that was positive for $C$. perfringens type A with the beta-2 toxin gene (cpb2) (Table 1). In total, 44 strains (91.7\%) of C. perfringens type A were positive for the $\mathrm{cpb} 2$ gene. Twenty-three of the strains $(52.3 \%)$ came from non-diarrheic piglets.

Histopathological evaluation did not reveal any alterations that could be directly linked to C. perfringens type A infection. No association was found between any type of histological lesion and the detection of $C$. perfringens type A cpb2+ ( $p=0.73)$. There was also no difference between the presence or absence of histopathological changes and the isolation of $C$. perfringens type $\mathrm{A}$, even disregarding the presence of the cpb2 gene.

\section{Clostridium difficile}

Thirteen piglets from six farms had mesocolon edema (Table 2), a common macroscopic alteration associated with $C$. difficile infection. Of these 13 animals, eight (61.5\%) were from the diarrheic group and five (38.5\%) were from the control group. Mesocolon edema was associated with six farms; at one of the farms, all four of the sampled animals presented with this macroscopic lesion.

Ten piglets $(16.7 \%)$ from six different farms were positive for $C$. difficile A/B toxins. Of these, seven were diarrheic piglets, and three were control piglets. Among the diarrheic piglets, two had mild neutrophilic colitis, one had moderate neutrophilic colitis and two had severe colitis (Fig.2b). The remaining two animals from the diarrheic group showed no histopathological alterations. All three of the control piglets that were positive for A/B toxins had neutrophilic colitis, two with severe and one with mild lesions.

Another six piglets, belonging to five different farms, were negative for the detection of A/B toxins by ELISA but had histological lesions compatible with $C$. difficile infection. Of the six, two belonged to the diarrheic group, one of which presented with mild colitis and the other with mo-

Table 2. Mesocolon edema and histological changes in diarrheic and non-diarrheic piglets

\begin{tabular}{cccc}
\hline Group & Mesocolon edema & \multicolumn{2}{c}{ Histopathological alterations* } \\
\cline { 3 - 4 } & & Enteritis & Typhocolitis \\
\hline Diarrheic piglets & $13.3 \%(4 / 30)$ mild & $10 \%(3 / 30)$ mild & $6.7 \%(2 / 30)$ mild \\
& $6.7 \%(2 / 30)$ moderate & $6.7 \%(2 / 30)$ moderate & $3.3 \%(1 / 30)$ moderate \\
& $6.7 \%(2 / 30)$ severe & $13.3 \%(4 / 30)$ severe & $10 \%(3 / 30)$ severe \\
Non-diarrheic & $6.7 \%(2 / 30)$ mild & $20 \%(6 / 30)$ mild & $6.7 \%(2 / 30)$ mild \\
piglets (control) & $6.7 \%(2 / 30)$ moderate & $6.7 \%(2 / 30)$ moderate & $3.3 \%(1 / 30)$ moderate \\
& $3.3 \%(1 / 30)$ severe & $6.7 \%(2 / 30)$ severe & $13.3 \%(4 / 30)$ severe
\end{tabular}

* For piglets with more than one microscopic lesion, the most serious was considered. 


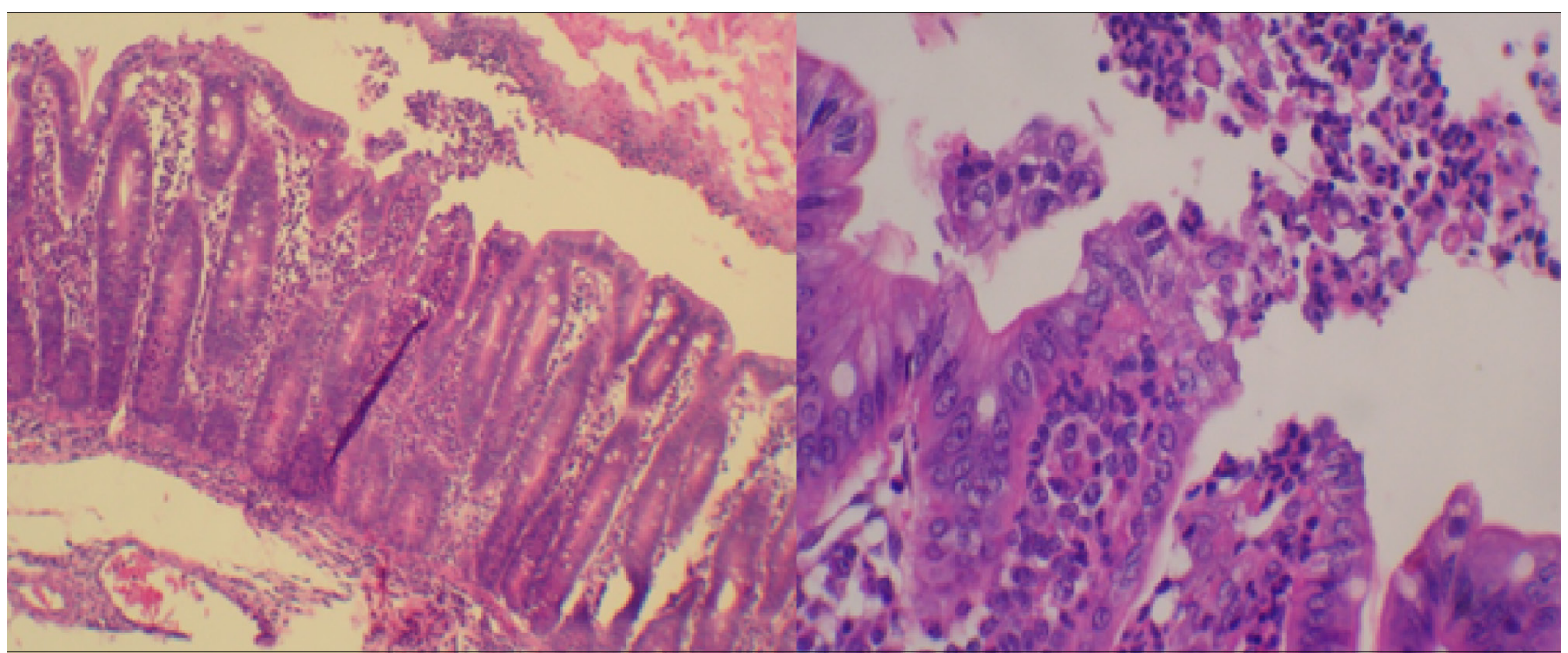

Fig.2. Colon sections of piglet with lesions suggestive of Clostridium difficile infection. (a) Severe goblet cell loss. HE, obj.4. (b) Severe necrotizing neutrophilic colitis with intense infiltration of neutrophils from the lamina propria to the intestinal lumen. HE, obj.40x.

derate colitis. In the control group, one piglet had mild colitis and the other three had severe colitis. Among all piglets with colitis, different degrees of reduction in the number of goblet cells were visualized, depending on the intensity of the associated inflammation.

\section{Rotavirus}

Four samples were positive for rotavirus by PAGE analysis, all of which came from different farms and belonged to the diarrheic group (Table 1). Among them, three had multifocal neutrophilic enteritis ranging from moderate to severe, with enterocyte necrosis in the tip of the villi suggestive of recent rotavirus infection (Fig.3). The remaining piglet showed no histological lesions.

\section{Isospora suis}

Two piglets from the control group were positive for fecal oocysts according to the flotation test (Table 1). Pa-

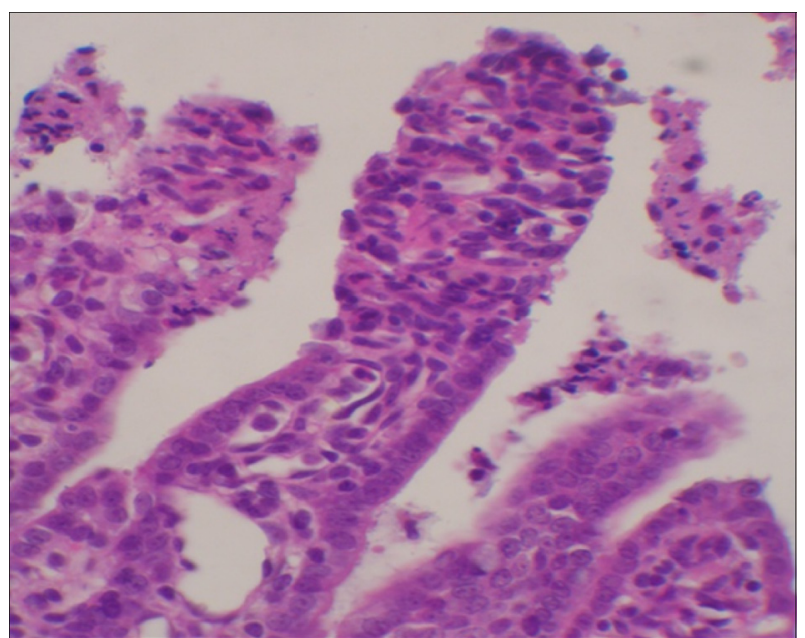

Fig.3. Jejunum section of a diarrheic piglet with suggestive rotavirus lesions. Severe neutrophilic necrotizing enteritis from the apex to the middle portion of the villi, area with total loss of enterocytes (white arrows). HE, obj.40x. rasitization of the enterocytes, which is typical in piglets with coccidiosis, was not found during histopathological examination.

\section{Coinfection}

Fourteen piglets from eight different farms were positive for more than one enteropathogen, nine from the diarrheic group and five from the control group. Among the diarrheic piglets, six were positive for $C$. perfringens type $\mathrm{A} \mathrm{cpb2+}$ and $C$. difficile toxins; one for $C$. perfringens cpb2+ type A and enterotoxigenic E. coli; and two for C. perfringens type $\mathrm{A} \mathrm{cpb2+}$ and rotavirus. Among the five non-diarrheic piglets with coinfection, three were positive for C. perfringens type A cpb2+ and C. difficile A/B toxins; one for C. perfringens cpb2+ type A and enterotoxigenic E. coli; and one for $C$. perfringens type A cpb2+ and I. suis oocysts. On one farm, three of the four sampled animals were simultaneously positive for $C$. difficile toxins and for other pathogens. In addition, C. perfringens type A cpb2+ was involved in all coinfections.

\section{DISCUSSION}

Suggestive colonies of Escherichia coli according to plating on MacConkey agar were obtained from all samples collected. Without further detection of virulence factor genes by PCR, the role of this organism as a causal agent of diarrhea would have been over-estimated. Such misinterpretation of results derived from non-routine identification methods could explain the increase of antimicrobial-resistant strains of $E$. coli isolated from piglets; resistance may arise from the misuse of drugs given against pathogens not directly associated with the disease being treated (Menin et al. 2008).

According to Francis (2002), newborn piglets with E. coli strains possessing virulence factors are commonly positive for LT, STB, K99 and 987P genes. Moreover, the same author reported that the presence of both toxin and fimbriae are necessary for infection by enterotoxigenic E. 
coli and the development of diarrhea. In the present study, two out of four piglets positive for E. coli with virulence factors did not have either fimbriae or toxin genes. One of these four piglets expressed F41 fimbriae, but was positive for Clostridium perfringens type A cpb2+. Thus, the role of each of these agents in causing diarrhea cannot be conclusively determined. The other piglet was positive for a fimbrial encoding gene (987P) but negative for all other pathogens studied. One possible explanation for the occurrence of diarrhea in this piglet is the excessive consumption of milk, a common cause of non-infectious diarrhea in piglets (Jennings 1959). This could also potentially explain diarrhea occurring in other piglets testing negative for the studied pathogens.

A few decades ago, several studies reporting a high incidence of enterotoxigenic E. coli in piglets (Barcellos et al. 1980, Calderaro et al. 2001) resulted in ETEC becoming regarded as the main cause of diarrhea in piglets up to seven days of age. However, recent studies have reported lower detection rates ranging from 3 to 20\% (Yaeger et al. 2007). The low frequency (6\%) of enterotoxigenic $E$. coli observed in our study supports these most recent studies and helps confirm the reduced occurrence of colibacillosis in young piglets. One factor that may be contributing to the decreased frequency in ETEC-caused diarrhea is routine vaccination against neonatal colibacillosis.

Although some authors associate C. perfringens type A cpb2+ infection with the presence of inflammatory infiltrates in the lamina propria and with mild to moderate necrosis of the enterocytes (Songer \& Glock 1998, Hammer \& Walz 2008, Farzan et al. 2013), others report the absence of pathological changes associated with this pathogen (Songer \& Uzal 2005). In our study, we observed no histological alterations that could be attributed to this agent. Yaeger (2007) also found no microscopic lesions in piglets with diarrhea caused by $C$. perfringens type $\mathrm{A} \mathrm{cpb} 2+$ and instead suggested that the agent was responsible for secretory diarrhea. However, any diagnosis of diarrhea due to this pathogen should be made cautiously, as $C$. perfringens type $\mathrm{A}$ is a normal part of the piglet intestinal microbiota. Detecting the presence of other possible pathogens or coinfection is therefore essential. Another diagnostic possibility commonly cited in the literature is the quantification of C. perfringens. In our study, quantification in SPS agar was performed, but no association was found between the presence or absence of diarrhea and the number of organisms (data not shown), corroborating previous studies (Songer \& Glock 1998, Farzan et al. 2013) which reported that the quantification of $C$. perfringens colony-forming units in intestinal or stool samples are not correlated with the presence of diarrhea in piglets.

The high isolation rate of $C$. perfringens type A cpb2+ from control piglets (76.7\%) was interesting because cpb2 strains are commonly associated with the occurrence of diarrhea or dysentery in pigs (Van Asten et al. 2010). The presence of cpb2+ in healthy animals; the absence of histological lesions in C. perfringens-positive animals (diarrheic or non-diarrheic); and the absent correlation between the quantity of organism and clinical disease, all suggest that the cpb2 gene is not an appropriate marker for determining the pathogenicity of $C$. perfringens type A. This results are similar to those recently reported by Farzan et al. (2013), which found no difference between the isolation of C. perfringens type A cpb2+ in diarrheic or non-diarrheic piglets. In addition, these authors also reported the absence of correlation between the detection of the beta- 2 toxin directly in the intestinal content in these two groups, suggesting that the isolation of $C$. perfringens type $\mathrm{A}$ cpb2+ or the detection of beta-2 toxin are not a useful approach for making diagnosis of type A C. perfringens enteritis in piglets (Farzan et al. 2013).

Six of the thirteen piglets with mesocolon edema (46\%) were positive for $C$. difficile A/B toxins by ELISA. This result supports Yaeger et al. (2007) who reported a low positive predictive value (54\%) between the presence of mesocolon edema and the detection of $C$. difficile A/B toxins. However, all piglets with severe mesocolon edema were positive for A/B toxins. Moreover, a significant association $(\mathrm{p}<0.004)$ was found between the absence of macroscopic lesions and the non-detection of A/B toxins regardless of the presence of diarrhea. Given these results, the presence of severe mesocolon edema should be considered an important indicator of $C$. difficile infection, while the complete absence of macroscopic alterations may indicate that the animal is negative for A/B toxin.

Of the 10 piglets positive for $A / B$ toxins by ELISA, five control piglets and three diarrheic piglets demonstrated histological inflammatory lesions. These results also support those of Yaeger et al. (2007) describing a higher positive predictive value $(76 \%)$ for the occurrence of neutrophilic inflammatory infiltrate in the lamina propria and detection of $\mathrm{A} / \mathrm{B}$ toxins. In addition, a significant association was found between the presence of microscopic alterations and the detection of the A/B toxin $(\mathrm{p}<0.0001)$, confirming that the occurrence of inflammatory lesions is associated with the toxin regardless of the presence or absence of diarrhea. These findings suggest that in the absence of an assay for the A/B toxin, histopathology could be used as a diagnostic tool to indicate possible involvement of $C$. difficile infection with diarrhea in piglets. In addition to these common microscopic inflammatory changes, Yaeger et al. (2007) also observed a reduction in the number of goblet cells and increased mitotic activity in the crypts. We made similar observations, including a significant decrease in goblet cells in the cecum and colon of piglets (Fig.2a).

Six piglets that were negative for A/B toxins had histological lesions suggestive of $C$. difficile infection, which may be related to the low sensitivity of the ELISA used. Different studies evaluating various commercially available ELISA kits using piglet stool samples indicated that they commonly lack sensitivity (Post et al. 2002, Songer \& Anderson 2006, Keessen et al. 2011).

The association between macroscopic findings, histological lesions and the presence of $\mathrm{A} / \mathrm{B}$ toxins confirms that complications related to $C$. difficile infection in piglets could occur without any clinical sign of diarrhea. Yaeger et al. (2007) reported similar findings, indicating that A/B-toxin-positive piglets can also suffer constipation or obstipation. 
It should be emphasized that on a farm with a suspected C. difficile infection, sampling for diagnosis should include animals with clinical signs of diarrhea as well as some non-diarrheic piglets. Furthermore, an assortment of different diagnostic tools should be used to confirm the diagnosis.

Among the four piglets testing positive for rotavirus by PAGE, only one presented with no histological lesions. This suggests that the piglet had only an initial infection because the onset of fecal shedding of rotavirus may precede the appearance of histological lesions (Linares et al. 2009). Our results demonstrate a $13.3 \%$ rotavirus- positive frequency in diarrheic piglets, a significant association between pathogen detection and the presence of diarrhea $(p \leq 0.05)$. Our rate in diarrheic piglets is higher than the $7.5 \%$ rate reported by Lippke et al. (2011) and similar to the 13\% rate reported by Yaeger (2007). In contrast, Gregori et al. (2009) reported a rotavirus frequency of $29.9 \%$ (as determined by PAGE) in stool samples from 144 piglets with clinical diarrhea; unfortunately, the authors did not report the age of the sampled animals. According to Roehe et al. (1989), piglets are most commonly infected by rotavirus between 15 and 30 days of age. Early rotavirus infection may therefore indicate a low colostrum intake or ineffective vaccination. Significantly, by 2011, the single commercially available rotavirus vaccine in Brazil included only the G5 and G4 serotypes of group A. However, Gregori et al. (2009) reports that the most common serotypes in Brazil are (in order): G5, G10, the non-defined genotypes and G6. Moreover, studies on vaccination efficacy and the occurrence of cross-protection are still rare.

The low detection rate for I. suis observed in this study substantiates other recent reports (Karamon et al. 2007, Yaeger et al. 2007) suggesting that coccidiosis is rare in piglets between one and seven days of age. Previous studies indicate that infection with I. suis may be more frequent during the second and third weeks of life (Martineau \& Castillo 2000).

\section{CONCLUSIONS}

Clostridium perfringens type A cpb2+ and C. difficile were the most frequently detected enteropathogens in 1to 7-day-old piglets, but an association between pathogen detection and histological alterations could only be observed for $C$. difficile.

The more often detection of $C$. perfringens type $\mathrm{A} \mathrm{cpb2+}$ in health piglets proved the cpb2+ detection to be an inefficient marker for determining the pathogenicity of C. perfringens type A isolates.

Among these two anaerobic pathogens, $C$. difficile detection results demonstrated the importance of testing diarrheic piglets for this agent.

Rotavirus screening should always be performed for piglets with enteric disorders. The combination of histopathology with other detection methods provided the best results for accurate diagnosis.

Conflict of interest statement.- None of the authors has any financial or personal relationships that could inappropriately influence or bias the content of the paper.
Acknowledgements.- This study was supported by funds from Capes, Fapemig and CNPq. RMC Guedes and FCF Lobato have a research fellowship from CNPq. The authors would like to thank Dr. Blanko Kokotovic for the discussions during the study design.

\section{REFERENCES}

Barbosa E.F. 1994. Vírus intestinais RNA de fita dupla em frangos de corte no sudoeste catarinense: isolamento, caracterização e biologia molecular. Tese de Doutorado em Medicina Veterinária, Universidade Federal de Minas Gerias, Belo Horizonte. 113p.

Barbosa E.F., Figueiredo H.C.P., Garcia A.M., Lobato Z.I.P. \& Lage A.P. 1998. Rotavírus do grupo A em bezerros lactentes no estado de Minas Gerais. Ciência Rural 28:435-439.

Barcellos D.E.S.N., Guizzardi I.I. \& Falavena L.C.B. 1980. Freqüência e causa de diarréias bacterinanas em suínos nas zonas criatórias do Vale do Taquari e Missões, Rio Grande do Sul, Brasil. Bolm Inst. Pesq. Vet. Desidério Finamor 80:27-37.

Baums C.G., Schotte U., Amtsberg G. \& Goethe R. 2004. Diagnostic multiplex PCR for toxin genotyping of Clostridium perfringens isolates. Vet. Microbiol. 100:11-16.

Calderaro F.F., Baccaro M.R., Moreno A.M., Ferreira A.J.P., Jerez A.J. \& Pena H.J.F. 2001. Frequência de agentes causadores de enterites em leitões lactentes provenientes de sistemas de produção de suínos do estado de São Paulo. Arqs Inst. Biológico, SãoPaulo, 68:29-34.

Farzan A., Kircanski J., DeLay J., Soltes G., Songer J.G., Friendship R. \& Prescott J.F. 2013. An investigation into the association between cpb2-encoding Clostridium perfringens type A and diarrhea in neonatal piglets. Can. J. Vet. Res. 77:45-53.

Francis D.H. 2002. Enterotoxigenic Escherichia coli infection in pigs and its diagnosis. J. Swine Health Prod. 10:171-175.

Gregori F., Rosales C.A.R., Brandão P.E., Soares R.M. \& Jerez J.A. 2009. Diversidade genotípica de rotavírus suínos no Estado de São Paulo. Pesq. Vet. Bras. 29:707-712.

Hammer J.M. \& Walz M. 2008. Serological evaluation of a Clostridium perfringens type A toxoid in a commercial swine herd. J. Swine Health Prod. 16:37-40.

Herring A.J., Inglis N.F., Ojeh C.K., Snodgrass D.R. \& Menzies J.D. 1982. Rapid diagnosis of rotavirus infection by direct detection of viral nucleic acid in silver-stained polyacrylamide gels. J. Clinic. Microbiol. 16:473477.

Hoffmann R.P. 1987. Diagnóstico de Parasitismo Veterinário. Editora Sulina, Porto Alegre. 156p.

Jennings A.R. 1959. Gastro-enteritis in the pig. Vet. Rec. 71:766-771.

Karamon J., Ziomko I. \& Cencek T. 2007. Prevalence of Isospora suis and Eimeria spp. in suckling piglets and sows in Poland. Vet. Parasitol. 147:171-175. DOI: 10.1016/j.vetpar.2007.03.029

Keessen E.C., Hopman N.E., Van Leengoed L.A., Van Asten A.J., Hermanus C., Kuijper E.J. \& Lipman L.J. 2011. Evaluation of four different diagnostic tests to detect Clostridium difficile in piglets. J. Clinic. Microbiol. 49:1816-21.

Linares R.C., Barry A.F., Alfieri A.F., Médici K.C., Feronato C., Grieder W. \& Alfieri A.A. 2009. Frequency of group a rotavirus in piglet stool samples from non-vaccinated Brazilian pig herds. Braz. Arch. Biol. Technol. 52:63-68. <http://dx.doi.org/10.1590/S1516-89132009000700009>

Lippke R.T., Borowski S.M., Marques S.M.T., Paesi S.O., Almeida L.L., Moreno A.M., Zlotowski P., Corbellini L.G. \& Barcellos D.E.S.N. 2011. Matched case-control study evaluating the frequency of the main agents associated with neonatal diarrhea in piglets. Pesq.Vet. Bras. 31:505-510.

Luna L.G. 1968. Manual of Histologic Staining Methods of the Armed Forces Institute of Pathology. McGraw-Hill Book Co., New York. 258p.

Macêdo N.R., Menezes C.P.L., Lage A.P., Ristow L.E., Reis A. \& Guedes R.M.C. 2007. Detecção de cepas patogênicas pela PCR multiplex e avaliação da sensibilidade a antimicrobianos de Escherichia coli isoladas de leitões diarréicos. Arq. Bras. Med. Vet. Zootec. 59:1117-1123.

Martineau G.P. \& Castillo J. 2000. Epidemiological, clinical and control in- 
vestigations on field porcine coccidiosis: clinical, epidemiological and parasitological paradigms? Parasitol. Res. 86:834-837.

Martins M.F., Nilce M.M.R., Ferreira A., Brocchi M., Yano T., Castro A.F.P. \& Silveira W.D. 2000. Pathogenic characteristics of Escherichia coli strains isolated from newborn piglets with diarrhea in Brazil. Vet. Microbiol. 76:51-59.

Menin A., Reck C., Souza D., Klein C. \& Vaz E. 2008. Agentes bacterianos enteropatogênicos em suínos de diferentes faixas etárias e perfil de resistência a antimicrobianos de cepas de Escherichia coli e Salmonella spp. Ciência Rural 38:1687-1693.

Post K.W., Jost B.H. \& Songer J.G. 2002. Evaluation of a test for Clostridium difficile toxins A and B for the diagnosis of neonatal swine enteritis. J. Vet. Diagn. Invest. 14:258-259.

Roehe P.M., Cunha A.C., Salvo E.O., Martins R.M. \& Oliveira L.G. 1989. Rotavirus em suínos na região sul do Brasil. Pesq. Vet. Bras. 9:45-49.

Sambrook J., Fritsch E.F. \& Maniatis T. 1989. Molecular Cloning: A laboratory manual. $2^{\text {nd }}$ ed. Cold Spring Harbor Laboratory Press, New York. 309p.

Songer J.G. \& Anderson M.A. 2006. Clostridium difficile: an important pathogen of food animals. Anaerobe 12:1-4.

Songer J.G. \& Uzal F.A. 2005. Clostridial enteric infections in pigs. J. Vet. Diagn. Investig. 17:528-536.

Songer J.G. \& Glock R.D. 1998. Enteric infection of swine with Clostridium perfringens types A and C. J. Swine Health Prod. 6:223-225.
Theil K.W., McCloskey C.M., Saif L.J., Redman D.R., Bohl E.H., Hancock D.D., Kohler E.M. \& Moorhead P.D. 1981. Rapid, simple method of preparing rotaviral double-stranded ribonucleic acid for analysis by polyacrylamide gel electrophoresis. J. Clin. Microbiol. 14:273-280.

Van Asten A.J., Nikolaou G.N. \& Gröne A. 2010. The occurrence of cpb2-toxigenic Clostridium perfringens and the possible role of the beta2-toxin in enteric disease of domestic animals, wild animals and humans. Vet. Journal 183:135-140.

Vieira A.A.S., Guedes R.M.C., Salvarani F.M., Silva R.O.S., Assis R.A. \& Lobato F.C.F. 2008. Genotipagem de Clostridium perfringens isolados de leitões diarréicos. Arqs Inst. Biológico, SãoPaulo, 75: 513-516.

Yaeger M.J., Funk N. \& Hoffman L. 2002. A survey of agents associated with neonatal diarrhea in Iowa swine including Clostridium difficile and porcine reproductive and respiratory syndrome virus. J. Vet. Diagn. Invest. 14:281-287.

Yaeger M.J., Kinyon J.M. \& Songer J.G. 2007. A prospective, case control study evaluating the association between Clostridium difficile toxins in the colon of neonatal swine and gross and microscopic lesions. J. Vet. Diagn. Invest.19:2-59.

Yaeger M.J. 2007. Prospective and retrospective studies on Clostridium perfringens type A enteritis in neonatal swine. Proceedings of the Annual Meeting of the American Association of Swine Veterinarians, Orlando, Florida, p.101-103. 